\title{
FASE PERKEMBANGAN MANUSIA DALAM PENDIDIKAN ISLAM
}

\section{Oleh : M. Ilyas ${ }^{1}$}

\begin{abstract}
Abstrak
Pendidikan Agama Islam merupakan suatu usaha untuk membina dan mengasuh peserta didik agar senantiasa dapat memahami kandungan ajaran Islam secara menyeluruh, menghayati makna tujuan, yang pada akhirnya dapat mengamalkan serta menjadikan Islam sebagai pandangan hidup. Fase perkembangan manusia akan melewati beberapa proses pendidikan yaitu, Pertama periode berawal dari nuthfah sampai menjadi mudhgah, dan kemudian menjadi seorang bayi. Kedua, setelah berbentuk daging (mudghah). Ketiga, aspek agama yang sebenarnya sudah ada pada setiap individu jauh sebelum kelahiran didunia nyata. Dalam suatu periode hidup manusia, terdapat fase-fase tertentu yang harus dilewati antara lain: fase pranatal, bayi baru lahir, masa bayi, masa kanak-kanak, masa remaja, masa dewasa, masa usia lanjut. pembahasan dalam jurnal ini adalah Pendidikan Qabl Al-Wiladah, Pendidikan Islam ba'da al-wiladah, manusia usia lanjut agama, perlakuan terhadap usia lanjut menurut Islam. Tujuannya adalah agar setiap manusia mampu melewati kehidupan dengan akan timbulnya karakter dan kebiasaan unik yang dimiliki oleh seseorang dengan baik sesusai dengan tuntutan agama setiap fase yang di laluinya.
\end{abstract}

\section{Kata Kunci : Perkembangan Manusia, Pendidikan Islam}

\section{Pendahuluan}

Pendidikan Agama Islam adalah upaya sadar dan terencana dalam menyiapkan peserta didik untuk mengenal, memahami, menghayati, hingga mengimani, bertaqwa dan berakhlak mulia dalam mengamalkan ajaran Islam dari sumber utamanya kitab Suci Al-Qur'an dan Hadits, melalui kegiatan bimbingan, pengajaran, latihan, serta penggunaan pengalaman.

Menurut Zakiah Daradjat, Pendidikan Agama Islam adalah suatu usaha untuk membina dan mengasuh peserta didik agar senantiasa dapat

${ }^{1}$ Dosen Tetap Program Studi Pendidikan Agama Islam dan juga merupakan Ketua STAI Auliaurrasyidin Tembilahan Kabupaten Indragiri Hilir Propinsi Riau. 
memahami kandungan ajaran Islam secara menyeluruh, menghayati makna tujuan, yang pada akhirnya dapat mengamalkan serta menjadikan Islam sebagai pandangan hidup.

Tayar Yusuf, medefinisikan Pendidikan Agama Islam sebagai usaha sadar generasi tua untuk mengalihkan pengalaman, pengetahuan, kecakapan dan keterampilan kepada generasi muda agar kelak menjadi manusia muslim, bertaqwa kepada Allah SWT, berbudi pekerti luhur, dan berkepribadian yang memahami, menghayati dan mengamalkan ajaran Agama Islam dalam kehidupannya. ${ }^{2}$ Sedangkan menurut Muhammad Quthb, Pendidikan Islam adalah usaha untuk melakukan pendekatan yang menyeluruh terhadap wujud manusia, baik dari segi jasmani maupun rohani, baik dari kehidupan-kehidupan fisik maupun mentalnya, dalam melaksanakan kegiatannya di bumi ini. ${ }^{3}$

\section{Pendidikan Islam}

Pendidikan Pra Konsepsi ini adalah salah satu upaya persiapan pendidikan yang dimulai ketika seseorang memilih pasangan hidupnya sampai pada saat setelah terjadinya pembuahan dalam rahim sang Ibu. Dalam kaitannya dengan hal ini, Islam telah mengajarkan hal-hal berikut:

a. Dalam memilih pasangan hidup, Islam mengajarkan agar mengutamakan pengetahuan agamanya yang sama-sama beragama Islam, dan juga memiliki perangai dan tingkah laku yang baik. Rasulullah SAW bersabda, yang artinya :

"Wanita itu dinikahi karena empat hal, yaitu karena kekayaannya, kecantikannya, keturunannya, dan karena agamanya, kamu pasti akan bahagia."

${ }^{2}$ Abdul Majid, Belajar dan Pembelajaran Pendidikan Agama Islam, Bandung: PT. Remaja Rosdakarya, 2012, h. 12.

${ }^{3}$ Abdullah Idi, Toto Suharto, Revitalisasi Pendidikan Islam, Yogyakarta: Tiara Wacana, 2006, h. 48. 
Berdasarkan hadits ini, sangatlah jelas bahwa kita memilih calon pasangan hidup, agama dan akhlak merupakan dua hal yang paling utama. Setelah kedua hal ini barulah faktor-faktor lain dipertimbangkan.

b. Mencari rejeki dan makanan yang halal. Seperti disebutkan dalam Q.S. An-Nahl : 114, yang artinya :

"Maka makanlah yang halal lagi baik dari rejeki yang telah diberikan Allah kepadamu; dan syukurilah nikmat Allah, jika kamu hanya kepadaNya saja menyembah."

Paparan ayat di atas memmberikan pemahaman bahwa apa yang kita konsumsi sehari-hari itu memiliki pengaruh yang sangat besar terhadap keturunan, baik itu fisik maupun mental. Selain itu, menurut disiplin ilmu biologi, makanan yang baik dan bergizi itu memiliki pengaruh yang besar terhadap pematangan ovum dan spermatozoa yang kemudian akan menjadi janin yang sehat dan kuat.

\section{Pendidikan Islam Masa Pranatal (Tarbiyah Qabl Al-Wiladah)}

Pendidikan Pranatal adalah pendidikan sebelum masa melahirkan. Masa ini ditandai dengan fase pemilihan jodoh, pernikahan, dan kehamilan. Berikut penjelasan beberapa fase tersebut.

\section{Fase Pemilihan Jodoh}

Fase ini adalah persiapan bagi seseorang yang sudah dewasa untuk menghadapi hidup baru yaitu berkeluarga. Salah satu pendidikan yang dimiliki oleh seseorang yang sudah dewasa itu adalah masalah pemilihan jodoh yang tepat. Sebab masalah ini mempengaruhi terhadap kebahagian rumah tangganya dikemudian hari. ${ }^{4}$

Menurut R.I Suhartin, memilih jodoh ada syarat dan kriterianya. Kriteria ini dibagi kepada dua golongan yakni; Kriteria umum dan Kriteria 
yang bersifat khusus (subjektif). Syarat kriteria umum adalah seyogyanya jodoh yang dipilih sudah dewasa agar tidak mengalami kesulitan dalam berkeluarga dan syarat kriteria khususnya tentu sesuai dengan selera masing-masing. Namun syarat yang terpenting adalah saling mencintai.

Berkenaan dengan pemilihan jodoh dalam perkawinan, Syariat Islam telah meletakkan kaidah-kaidah dan hukum-hukum bagi masingmasing pelamar dan yang dilamar, yang apabila petunjuknya itu dilaksanakan maka perkawinan akan berada pada puncak keharmonisan, kecintaan dan keserasian.

Rasulullah SAW telah memberikan gambaran dalam haditsnya mengenai pemilihan calon istri atau suami. Berikut ini adalah beberapa hadits yang berkenaan dengan pemilihan jodoh diantaranya:

1) Pemilihan Calon Istri

Sabda Rasulullah SAW yang artinya :

"Dunia ini adalah perhiasan, sebaik-baiknya perhiasan adalah wanita yang shalehah.” (HR. Muslim).

Dari penjelasan hadits Rasulullah di atas, maka dapatlah diambil beberapa syarat yang penting untuk memilih calon istri diantaranya:

a) Saling mencintai antara calon kedua mempelai.

b) Memilih wanita karena agamanya agar nantinya mendapat berkah dari Allah SWT.

c) Wanita yang sholehah.

d) Sama derajatnya dengan calon mempelai.

e) Wanita yang hidup dilingkungan yang baik.

f) Wanita yang jauh keturunannya dan jangan memilih wanita yang dekat sebab dapat menurunkan anak yang lemah jasmani dan memiliki IQ yang rendah. 
g) Wanita yang gadis dan subur (bisa melahirkan) lebih diutamakan. ${ }^{5}$

2) Pemilihan Calon Suami

Tidak banyak hadits yang menyebutkan tentang pemilihan calon suami sebagaimana halnya memilih calon istri. Aka tetapi dalam rangka memberikan keterangan terhadap penjelasan sub pembahasan ini. Penulis kemukakan beberapa di antaranya adalah Rasulullah SAW bersabda yang artinya:

"Apabila kamu sekalian didatangi seseorang yang agama dan akhlaknya kamu ridhai, maka kawinkanlah ia. Jika kamu sekalian tidak melaksanakannya maka akan menjadi fitnah dimuka bumi ini dan tersebarlah kerusakan.” (HR. Tirmidzi)

Berdasarkan hadits tersebut, maka jelaslah bahwa hal yang paling penting dalam memilih calon suami adalah melihatnya dari sudut pandang agama yang dianutnya dan akhlak yang dimilikinya.

\section{Fase Perkawinan/Pernikahan}

Beberapa aspek yang dijelaskan oleh syariat Islam yang berhubungan dengan anjuran pernikahan/perkawinan antara lain :

1) Perkawinan merupakan Sunnah Rasul

Sabda Nabi:

"Siapa saja yang mampu menikah, namun ia tidak menikah, maka tidaklah termasuk dalam golonganku.” (HR. Thabrani dan Baihaki).

2) Perkawinan untuk ketentraman kasih sayang

Firman Allah:

"Dan diantara tanda-tanda kekuasaan-Nya ialah, dia menciptakan untukmu istri-istri dari jenismu sendiri supaya kamu cendrung tentram kepada-Nya. Dan dijadikannya diantara kamu rasa kasih sayang. Sesungguhnya yang demikian itu benar-benar terdapat tanda-tanda bagi kaum yang berpikir." (QS. Ar-Rum : 21). 
3) Perkawinan untuk mendapatkan keturunan

Bagaimana anak memasukkan ayah dan ibunya kedalam Surga? Mari kita mencermati bagaimana jawabannya dari Rasulullah SAW dalam hadits Qudsi. Imam Ahmad meriwayatkan dari sebagian Sahabat Nabi Shallalla'alaihi Wassalam, bahwa beliau bersabda:

"Di perintahkan kepada anak-anak di Surga: "Masuklah kedalam Surga.' Mereka menjawab: "Wahai Rabb-ku (kami tidak masuk) hingga bapak dan ibu kami masuk (terlebih dahulu).' ketika mereka (bapak dan ibu) datang, maka Allah Azza wa Jalla berfirman kepada mereka: aku tidak melihat mereka terhalang. Masuklah kalian kedalam Surga.' Mereka mengatakan: Wahai Rabb-ku, bapak dan ibu kami?' Allah berfirman: 'Masuklah kedalam Surga bersama orang tua kalian. "6

4) Perkawinan untuk memelihara pandangan dan menjaga kemaluan dari kemaksiatan. At-Tirmidzi meriwayatkan dari Abu Hurairah Radhiyallahu anhu, bahwa Rasulullah SAW bersabda:

"Ada tiga golongan yang pasti akan ditolong oleh Allah; seorang budak yang ingin menebus dirinya dengan mencicil kepada tuannya, orang yang menikah karena ingin memelihara kesuciannya, dan pejuan di jalan Allah."

Setelah itu calon dipilih, diadakan peminangan dan selanjutnya dilaksanakan pernikahan dengan Walimatul Al-Ursy nya.

\section{Fase Kehamilan}

Salah satu tujuan berumah tangga adalah untuk mendapatkan keturunan, karena itu seorang istri mengharapkan ia dapat melahirkan seorang anak. Sebagai tanda seorang istri akan memiliki anak adalah melalui proses kehamilan selama lebih kurang 9 bulan. Masa kehamilan memiliki beberapa tahapan, yaitu:

${ }^{6}$ https://almanhaj.or.id/3565-anjuran-untuk-,menikah.html, diakses pada 02 Oktober 2018, pkl. 17.51 WIB. 
1) Tahapan Nuthfah. Pada tahap ini, calon anak masih dalam bentuk cairan sperma dan sel telur. Tahap ini berlangsung selama 40 hari.

2) Tahap 'Alaqah. Tahapan ini tentunya terjadi setelah janin berumur dalam 80 hari, cairan tersebut berkembang bagaikan segumpal darah kental dan bergantung pada dinding rahim ibu.

3) Tahap Mudghah. Tahapan ini terjadi pada saat janin berumur 120 hari, segumpal darah tadi berkembang menjadi segumpal daging. Pada masa inilah, calon bayi telah siap menerima hembusan ruh dari Malaikat utusan Allah.

Ada tiga faktor yang perlu dibicarakan berkaitan dengan proses pendidikan. Pertama diyakini bahwa periode ini berawal dari adanya kehidupan. Hal ini dinyatakan dengan adanya perkembangan yang berawal dari nuthfah sampai menjadi mudhgah, dan kemudian menjadi seorang bayi; Kedua, setelah berbentuk daging (mudghah), Allah mengutus malaikat untuk meniupkan ruh kepadanya. Tampaknya, ruh inilah yang menjadi tahap awal bergeraknya kehidupan psikis manusia. Disisi lain, perkembangan psikis manusia juga dipengaruhi oleh kegembiraan ataupun penderitaan yang dialami oleh sang ibu. Kebahagian, kelincahan ataupun kesedihan, kemurungan yang ditujukkan oleh sang ibu ketika mengandung akan tercermin kepada tingkah laku bayi yang dilahirkan. Ketiga, aspek yang paling penting adalah aspek agama. Naluri agama sebenarnya sudah ada pada setiap individu jauh sebelum kelahirannya didunia nyata.

Menurut Zakiah Daradjad, proses pendidikan lebih berpengaruh kepada anak apabila diamalkan langsung orang tuanya selama janin berada dalam kandungan. Kontak psikis secara langsung antara orang tua, terutama ibu dengan janin sebenarnya disebut pendidikan pada masa kehamilan. ${ }^{7}$

${ }^{7}$ Zakiah Daradjat, Bahan Kuliah Ilmu Pendidikan Islam, (PPs. IAIN Imam Bonjol Padang, 1996), h. 7. 


\section{Pendidikan Islam Masa Pascanatal (Tarbiyah Ba'da Al-Wiladah)}

Pendidikan pascanatal yaitu pendidikan yang dimulai sejak lahirnya anak sampai mereka dewasa, bahkan sampai meninggal dunia yang kita kenal dengan sebutan pendidikan seumur hidup. Dalam upaya pengembangan pendidikan agama dalam keluarga, Rasulullah SAW telah memberikan tuntunan kepada kita agar mendidik anak sesuai dengan perkembangan jiwanya. Ada beberapa tahapan dengan perkembangan jiwa anak yaitu:

\section{Usia anak 0-3 tahun}

Pada masa anak usia 0-3 tahun yang dapat dilakukan kedua orang tua adalah memberikan suasana kehidupan yang agamis seperti yang dianjurkan oleh Rasulullah SAW, seperti:

1) Membaca adzan pada telinga kanan dan iqamat pada telinga kiri sang bayi pada saat baru dilahirkan.

2) Menaqiqahkannya, disamping sebagai rasa syukur atas kelahiran anak, juga mengajarkan kepada anak agar suka bersedekah dan pandai bersyukur dikemudian hari dalam menjalani kehidupannya.

3) Memberikan nama kepada anak dengan nama yang baik.

4) Anak dicukur rambutnya / dibersihkan dari kotorannya.

5) Setelah sampai usia 3 tahun, hendaknya selalu diberikan suasana agamis dan dibiasakan dengan kebaikan semisal memperdengarkan bacaan AlQur'an kepadanya. ${ }^{8}$

\section{Fase Pra Sekolah (3-6 tahun)}

Karakteristik anak pada fase ini adalah:

1) Dapat mengontrol tindakannya.

2) Selalu ingin bergerak adalah sesuatu yang alami.

\footnotetext{
${ }^{8}$ Ramayulis, Op.Cit., h. 313.
} 
3) Berusaha mengenal lingkungan sekeliling, perkembangan yang cepat dalam berbicara.

4) Senantiasa ingin memiliki sesuatu, egois, keras kepala, suka protes, menanyai sesuatu berulang kali.

5) Mulai membedakan antara yang benar dan yang salah, yang baik dan yang buruk.

6) Mulai mempelajari dasar perilaku sosial. ${ }^{9}$

\section{Usia 7-13 tahun}

Pada usia ini anak sudah mulai memasuki SD karena sudah mulai dapat menggunakan pikiran / rasionya. Dalam upaya pendidikan Islam, Rasulullah telah mengajarkan pada hadits yang artinya:

"Suruhlah anak-anak melakukan ibadah shalat pada usia 7 tahun dan bilamana sampai usia 10 tahun belum shalat, maka pukullah ia. Dan pisahkan tempat tidurnya."

\section{Masa Remaja}

Masa ini berlangsung dari umur 12-21 tahun. Pada masa remaja ini ditandai dengan adanya perubahan yang menyangkut gender sehingga sering juga disebut dengan peralihan dari aseksual menjadi seksual. Selain itu, terjadi pula perubahan fisik dan perubahan psikis.

\section{Masa Dewasa}

Usia dewasa dimulai sejak berakhirnya kegoncangan-kegoncangan kejiwaan yang menimpa masa remaja. Dengan demikian, usia dewasa bisa dikatakan ketenangan jiwa, ketetapan hati dan keimanan yang tegas.

Sejalan dengan tingkat perkembangan usianya, Jalaluddin mengatakan sikap keagamaan pada orang dewasa memiliki ciri-ciri yaitu:

${ }^{9} \mathrm{Abu}$ Amr Ahad Sulaiman, Metode Pendidikan Anak Muslim Usia Prasekolah, Trj. Ahad Amin Sjihab, Judul Asli : Minhajuth Thiflil fii Dhau Al-Kitab wa As-Sunnah, Cet. I, (Jakarta: Yayasan Al-Sofwa, 2000), h. 10. 
1. Menerima kebenaran agama berdasarkan pertimbangan yang matang bukan sekedar ikut-ikutan.

2. Cenderung bersifat realistis sehingga norma-norma agama lebih banyak diaplikasikan dalam sikap dan tingkah laku.

3. Bersikap positif terhadap ajaran dan norma-norma agama dan berusaha untuk mempelajari dan memperdalam keagamaan.

4. Tingkat ketaatan beragama didasarkan atas pertimbangan dan tanggung jawab diri, hingga keberagamaan merupakan realisasi dari sikap hidup.

5. Bersikap lebih terbuka dan wawasan yang luas.

6. Bersikap lebih kritis terhadap materi ajaran agama sehingga kemantapan beragama selain didasarkan atas pertimbangan pemikiran juga didasarkan atas pertimbangan hati nurani.

7. Sikap keberagamaan cendrung mengarah kepada tipe-tipe kepribadian masing-masing sehingga terlihat adanya pengaruh kepribadian dalam menerima, memahami serta melaksanakan ajaran agama yang diyakininya. ${ }^{10}$

\section{Manusia Usia Lanjut Agama.}

\section{Perkembangan Jiwa Agama Pada Usia Lanjut.}

Pada perkembangan usia remaja Elizabeth B. Hurlock membagi masa dewasa menjadi tiga yaitu: masa dewasa awal, masa dewasa madya, masa usia lanjut. Klasifikasi senada juga diungkap oleh Lewis Sherril yang membagi masa remaja sebagai berikut :

1. Masa Dewasa Awal, masa ini remaja ada kecendrungan memilih arah hidup dengan menghadapi godaan berbagai kemungkinan pilihan.

2. Masa Dewasa Tengah, pada masa ini sudah mulai menghadapi tantangan hidup. Pada masa ini adalah masa dimana sudah mencapai pandangan

\footnotetext{
${ }^{10}$ Jalaluddin, Psikologi Agama, (Jakarta: Raja Grafindo Persada, 1998), h. 52.
} 
hidup yang matang dan utuh yang dapat menjadi dasar dalam membuat keputusan yang konsisten.

3. Masa Dewasa Akhir yang ciri utamanya adalah pasrah.

Manusia disebut makhluk yang memiliki prinsip tanpa daya, karena untuk perkembangan dan pertumbuhan secara normal manusia memerlukan bantuan dari luar dirinya. Bantuan yang dimaksud antara lain dalam bentuk bimbingan dan pengarahan dari lingkungannya. Bimbingan dan pengarahan yang diberikan dalam membantu perkembangan tersebut pada hakekatnya diharapkan sejalan dengan kebutuhan manusia itu sendiri, yang sudah tersimpan sebagai potensi bawaan. Agar efektif maka manusia harus menjalani tahapan-tahapan hidupnya dengan baik.

Dalam suatu periode hidup manusia, terdapat fase-fase tertentu yang dilewati antara lain: fase pranatal, bayi baru lahir, masa bayi, masa kanak-kanak, masa anak-anak, masa puber, masa remaja, masa dewasa, masa usia madya dan masa usia lanjut. Salah satu fase yang paling sering dibicarakan dan menarik perhatian para psikolog adalah fase madya dan fase lanjut usia (manula). Hal ini dikarenakan timbulnya karakter dan kebiasaan unik yang dimiliki oleh seseorang ketika memasuki usia lanjut yaitu berkisar antara umur 70-100 tahun atau sampai meninggal.

Perkembangan jiwa agama pada usia lanjut terdapat pada masa awal, tengah dan akhir. Dalam perkembangannya manusia membutukan bantuan baik itu dari dalam dan dari luar seperti bimbingan dan pengarahan dari lingkungannya.

\section{Karakteristik Keberagaman di Usia Lanjut}

Secara garis besar karakteristik keberagaman pada usia lanjut adalah sebagai berikut:

a. Kehidupan keagamaan pada usia lanjut telah mencapai tingkat kemantapan / kematangan beragama. 
b. Meningkatnya kecendrungan untuk menerima pendapat keagamaan.

c. Mulai muncul pergaulan terhadap realitas tentang kehidapan akhirat secara lebih bersungguh-sungguh.

d. Sikap keberagamaan cendrung mengarah kepada kebutuhan saling cinta antara sesama manusia secara sifat-sifat luhur.

e. Timbul rasa takut kepada kematian yang meningkat sejalan dengan pertambahan usia lanjut.

f. Perasaan takut kematian yang berdampak pada peningkatan pembentukan sikap keagamaan dan kepercayaan terhadap kehidupan abadi (akhirat).

\section{Perlakuan Terhadap Usia Lanjut Menurut Islam}

Manusia usia lanjut dalam penilaian banyak orang adalah manusia yang sudah tidak produktif lagi. Kondisi fisik rata-rata sudah menurun, sehingga dalam kondisi yang sudah uzur ini berbagai penyakit siap untuk menggerogoti mereka. Dengan demikan, di usia lanjut ini terkadang muncul semacam pemikiran bahwa mereka berbeda pada sisa-sisa umur menunggu datangnya kematian.

Lain halnya konsep yang dianjurkan dalam Islam. Perlakuan terhadap orang tua yang berusia lanjut dibebankan kepada anak-anak mereka, bukan kepada badan atau panti asuhan, termasuk panti jompo. Perlakuan terhadap orang tua menurut tuntunan Islam berawal dari rumah tangga. Allah menyebutkan pemeliharaan secara khusus orang tua yang sudah lanjut usia dengan memerintahkan kepada anak-anak mereka untuk memperlakukan kedua orang tua mereka dengan kasih sayang. Menurut AsShobuny, yang dimaksud dengan firman Allah yang artinya:

"Barang siapa kami panjangkan umurnya, niscaya kami kembalikan dia kepada kejadian (nya). Maka apakah mereka tidak memikirkannya.” (QS. Yassin : 68). 
Firman Allah SWT di atas menggambarkan bagaimana perlakuan terhadap manusia usia lanjut menurut Islam. Manusia usia lanjut dipandang tak ubahnya seorang bayi yang memerlukan pemeliharaan dan perawatan serta perhatian khusus dengan penuh kasih sayang. Perlakuan yang demikian itu tidak dapat diwakilkan kepada siapapun, melainkan menjadi tanggung jawab anak-anak mereka. Perlakuan yang baik dan penuh dengan kesabaran serta kasih sayang dinilai sebagai kebaktian. Sebaliknya perlakuan yang tercela dinilai sebagai kedurhakaan. Perlakuan terhadap manusia usia lanjut menurut Islam merupakan kewajiban agama, maka sangat tercela dan dipandang durhaka bila seorang anak tega menempatkan orang tuanya ditempat penampungan atau panti jompo. Alasan apapun tidak dapat diterima bagi perlakuan itu.

\section{Kesimpulan}

Pendidikan Islam masa pranatal disebut juga dalam bahasa arab tarbiyah qabl al-wiladah, pendidikan pranatal adalah pendidikan sebelum masa melahirkan yang ditandai dengan fase pemilihan jodoh, pernikahan, dan kehamilan. kemudian berlanjut kepada fase pendidikan Islam masa pascanatal atau tarbiyah $b a^{\prime} d a$ al-wiladah, pendidikan pascanatal yaitu pendidikan yang dimulai sejak lahirnya anak sampai mereka dewasa, bahkan sampai meninggal dunia yang kita kenal dengan sebutan pendidikan seumur hidup.

Upaya perkembangan jiwa pendidikan agama sangat penting untuk setiap fase yang dilaluinya, terutama ketika diberikan nikmat kesehatan karena akan datang masa dimana kondisi fisik menurun, sehingga dalam kondisi yang sudah uzur berbagai penyakit siap untuk menggerogoti kita. dengan demikan, di usia lanjut ini terkadang muncul semacam pemikiran bahwa mereka berbeda pada sisa-sisa umur untuk menunggu datangnya kematian. 


\section{Referensi}

Baharuddin, 2008. Psikologi Agama dalam Perspektif Islam. Malang: UINMalang Press.

Bahreisj, Hussein. Al Jamius Shahih Bukhari Muslim. Surabaya: Karya Utama. Tt.

Bambang Syamsul Arifin. 2015. Psikologi Agama. Bandung: CV. Pustaka Setia.

Daradjat, Zakiah. 1996. Bahan Kuliah Ilmu Pendidikan Islam. PPs. IAIN Imam Bonjol Padang.

http://almanhaj.or.id/3565-anjuran-untuk-menikah.html, diakses pada 02 Oktober 2018, Pkl. 17.51 WIB.

Jalaluddin. 1998. Psikologi Agama. Jakarta: Raja Grafindo Persada. , 2009. Psikologi Agama. Jakarta: Raja Grafindo Persada.

Raharjo. 2012. Pengantar Ilmu Jiwa Agama. Semarang: Pustaka Rizki Putra.

Ramayulis. Ilmu Pendidikan Islam. Jakarta: Kalam Muliya. tt.

Sulaiman, Abu Amr Ahad. 2000. MetodePendidikan Anak Muslim Usia Prasekolah. Trj. Ahad Amin Sjihab. Judul Asli: Minhajuth Thiflil fii Dhau Al-Kitab wa As-Sunnah. Cet. I. Jakarta: Yayasan AlSofwa.

Sururin. 2004. Ilmu Jiwa Agama. Jakarta: Raja Grafindo Persada. 